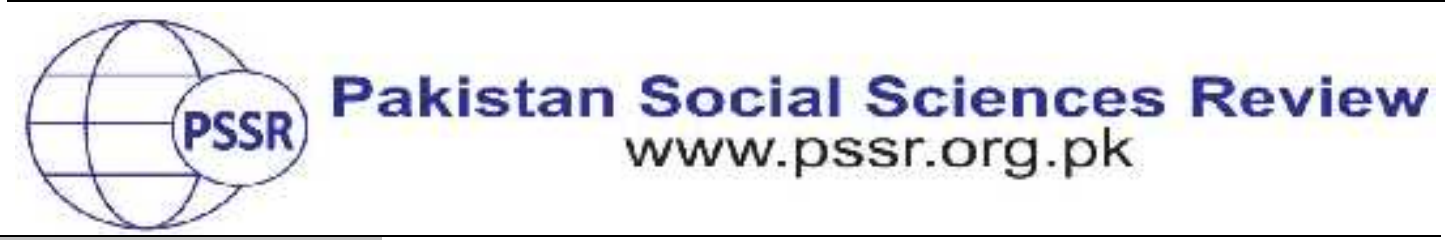

RESEARCH PAPER

\title{
Impact of Ethics of Care on Secondary School Students' Learning: Evidence from Pakistan
}

\author{
Fozia Gulab * 1 Dr. Shams Hamid ${ }^{2}$
}

1. PhD Scholar, Faculty of Education, Iqra University, Karachi, Sindh, Pakistan

2. Associate Dean,, Faculty of Fashion Design, Education, and Media Science, Iqra University, Karachi, Sindh, Pakistan

\begin{tabular}{|c|c|}
\hline PAI & ACT \\
\hline 2021 & $\begin{array}{l}\text { teachers and Grade } \\
\text { regarding the impa } \\
\text { study employed a q } \\
\text { study method to ex }\end{array}$ \\
\hline $\begin{array}{l}\text { ords: } \\
\text { nships } \\
\text { ts' Learning }\end{array}$ & $\begin{array}{l}\text { and } \\
\text { udy } \\
\text { ting } \\
\text { hatic } \\
\text { e in }\end{array}$ \\
\hline sponding & $\begin{array}{l}\text { e. cognitive and affective domains of learning. } \\
\text { is study brings an increased awareness on } \\
\text { are in students' lives and its role in their }\end{array}$ \\
\hline
\end{tabular}

\section{Introduction}

The education system in Pakistan is exposed to many problems and one of them is the quality and commitment of teachers towards the learning of students (Aly, 2007; Rashid \& Mukhtar, 2012). Some teachers appear to be barely concerned about the learning outcomes of their students. They evaluate students' learning based on the memorizing of facts and the accuracy of factual information to pass examinations. Consequently even university degree holders and graduates lack essential academic skills including reflection, critical thinking, analysis, research and creativity (Ahmad et. al. 2014; Rashid \& Mukhtar, 2012). Many research studies report factors such as less engagement of teachers with the students, lack of motivation for teaching, corporal punishment, bullying in classrooms and disruptive behaviour of the students as prevailing in the mainstream public schools. These factors show an uncaring environment hindering positive learning of the students (Ahmed et. al. 2013; Ghazi et. al. 2013; Mughal, 2020) 
It has been commonly observed that the students who are not supported by the teachers in their learning process remain uncertain about their talents and capabilities. Consequently, lack of teachers' support and care can also result in creating a tendency of making students self-centered and selfish(Engster \& Hamington, 2015; Owens \& Ennis, 2005).

An investment in students' learning can be made by the teachers through the creation of a learning-conducive environment in the classroom as students are usually responsive to teachers who care and get them actively engaged in the learning process. Relationships between teachers and students can encourage and motivate students to be active recipients and participants of the learning process (Engster \& Hamington, 2015; Owens \& Ennis, 2005).

Many empirical research studies support the claim that caring relationships with the teachers provide students a greater chance of academic success as compared to the situations where they do not enjoy such relationships. For instance, Goldstein and Lake (2000) have reported about the teachers making extra efforts for the struggling students resulting in an impact on their academic achievements. Similarly, Watson et. al. (2016) observed that caring relationships between teachers and the students from marginalized communities helped them in achieving excellence in learning. Many other studies (e.g. Garrett et. al. (2009) Narinasamy (2018) Rojas and Liou (2017) Thornberg and Oguz (2016) etc.) have also asserted the direct impact of caring attitudes of teachers on students' learning.

The ethics of care is at the heart of educational institutions and its purpose in education is the sustainability of reciprocal relationships between teachers and students in order to attain high academic and personal nourishment for a sustainable future. Relationships developed and maintained based on the ethics of care foster mutual recognition and realization, growth, development, protection, empowerment, along with human community, culture, and possibility. Thus 'care' is a necessary precondition 'for' education as well as an essential ingredient 'in' quality education to meet the needs of the students (Mortari 2016; Nguyen, 2016; Owens \& Ennis, 2005).

Caring teachers are needed in Pakistan's context to instill care within students, and one way to do this is through the development of positive relationships between teachers and students based on engrossment and motivational displacement. Teachers should display and provide care because it is crucial to strengthen the foundations of good teaching and learning.

\section{Literature Review}

Caring encompasses emotions, actions, behaviours, attitudes and reflections involving kindness, sympathy, empathy and a desire to motivate and inspire others (O'Connor, 2008). Caring further implies that emotions and feelings are more important than rigidly formulated principles and rules and although care emerges 
out of emotions, it is not just a sentiment or feeling. It requires empathy and sympathy accompanied by positive actions to be practiced by the caregivers to those for whom they are caring (Hamington, 2010; Louis et al., 2016; Monchinski, 2010; Silverman, 2012; Watson et al., 2016).

In the theoretical literature, the conception of care stems from the work of Gilligan (1982) and Noddings (1984). These groundbreaking works have opened a new horizon for the researchers to do empirical studies supporting, expanding or challenging these theories, particularly its implications on students' learning (Bergmark \& Alerby, 2006). Learning is considered as process that facilitates in developing and acquisition of knowledge, skills and attitudes to perform activities of daily life. In 1956, a group of researchers led by Benjamin Bloom categorized learning into three domains i.e. cognitive, affective and psychomotor, each domain containing varying level of learning starting from basis and ending with complex and deeper level of learning (Hoque, 2016).

The published empirical literature does not inform the impact of care on specific domain of learning. However, the literature informs thatthe caring attitudes of the teachers help the students to develop positive attitudes forlearningin general and thereby help them to improve their academic progress (Louis et al., 2016). In the study conducted by Goldstein and Lake (2000) participant prospective teachers reported that giving extra time and making efforts with care benefit students by enhancing their learning. They also regarded teachers to have a power to influence the students' lives with their teaching. Their spoken remarks could crush the students' self-esteem and confidence as they could also motivate them to succeed. The same concept is presented by Noddings (2003) where she asserts that the teachers have a power to uplift or degrade students with their words and attitudes.

Noddings (2003) asserts that the teacher's responsibility is not confined to introducing content to the students but to build a relationship of care and trust with them for their holistic development. In this regard, respect is a significant element and a necessary requirement to nourish a caring relationship between teacher and students. When students believe that they as individuals are being respected and valued by their teachers then it helps in building a positive teacher-student relationship.

When the teachers show care to slower learners, it helps them not to get demotivated by the academic difficulties and gradually achieve academic success. Care and a loving attitude towards the students help them to cope up with the negative forces that make them feel stressed and fearful of the failures. However, when caring is only confined to feeling sorry for the unprivileged status of students, and thereby setting low expectations of them, could result in negative outcomes for the students. By setting high expectations, challenging students to achieve their goals and at the same time assuring them their ongoing and continuous support teachers can help them achieve success. Caring teachers also need to have a sound knowledge of the socio-cultural context of the students so as to tailor appropriate individualized strategies to address their needs. Struggling students can achieve success when they 
believe they can do it and when they know that their teachers also believe in their growth and are willing to support them. Therefore, the teacher needs to ensure students feel that each of them is special regardless of his/her accomplishment in the class. They need to customize the pedagogies suited to learning styles of the students and support them to prevent facing failure (Rivera-McCutchen, 2012).

Watson et. al. (2016) report that when the teachers formed informal bonds and caring relationships with students from marginalized communities, such as Eskimos and American Indians, it had a direct positive impact in their classroom performances.To explain how a caring attitude of a teacher impacts the learning of the students, Owens and Ennis (2005) report that some of the participant students stated the caring attitude of their teachers was a primary cause of their academic success. The students asserted that when they see their teachers working hard and making extra efforts for their students' success, then the students are also motivated to work hard for their studies so as not to make their teachers' efforts wasted.

In O'Connor's (2008) study caring and positive relations were seen to motivate students to work hard and make extra efforts to learn as an act of showing gratitude to caring-teachers so as not to upset them. Students need to be reminded that a teacher's efforts are focused on students' achieving academic growth and success. In this way, teachersgain happiness and professional satisfaction by being emotionally involved with the students to make them academically succeed (O'Connor, 2008).

A teacher's caring attitude shapes students' discipline, autonomy, effort and engagement in school activities along with improvement in students' attendance and punctuality. Furthermore studies have found that students' engagement in school is a direct result of a teacher's caring attitude which has a far greater impact than the support provided by the parents and their class fellows. Particularly during adolescence, what students feel about their school and what they do in school depends largely on their relations with the teachers. During adolescence, young boys and girls try to develop their identity outside their family and parental bounds. At this stage, the teachers can address their needs by providing them more experiences of cooperative learning with their colleagues. This would help in bridging academic development with social development and result in culture of care (Narinasamy 2018; Owusu-Ansah \& Kyei-Blankson, 2016).

Fostering a caring environment in schools contributes to students' academic performance. It becomes an essential source of intrinsic motivation for learning. The teachers' modeling of caring attitudes and planning care embedded educational experiences for the students can foster a culture of care in the classroom (Noddings, 2012). Many research studies in the global contexts inform the importance of care and its impact on students' performance however, there is a dearth of research studies in Pakistani context about it. This research will attempt to address the gap. 


\section{Material and Methods}

This research specifically aims to generate an understanding ofthe impact of teachers' caring attitudes on the learning of students and to analyse administrators, teachers and students' perceptions of the relevance of care in education and its influence on student learning.

Using multiple case study design within the qualitative research paradigm, administrators, teachers and students' perceptions about the impact of the ethics of care on the learning of students in selected secondary schools were explored.The use of multiple case study design allowed for thedetailed exploration, depiction, examination and investigation of a phenomenon within its real context (Cohan et al., 2018; Gay et al., 2015; Merriam, 2009).

The study used purposive sampling and the sample comprised of theadministrators, teachers and students of grades ninth and tenth pre-medical group, academic year 2020-2021, in two private schools, St. Sylvester High School and Aly Salman High School located in Karachi, under the administration and management of National Catholic Education Commission (NCEC) and Aga Khan Education Service, Pakistan (AKESP) respectively. There are many common aspects in both the schools such as both the schools currently serves over 2500 students with classes ranging from preprimary to the secondary level. The students in both the schools come from medium to low socio-economic backgrounds. The mandate of both the schools is to serve beyond the boundaries of caste, colour, creed, race or nationalityand to empower men and women to become self-reliant individuals. Both the schools as mentioned in their mission statements, attempt to bridge therealms of faith and world with the aim of preparing individuals who can contribute positively in their societies.In both the schools, the students of grades ninth and tenth appear for the similar external exams entitled Secondary School Certificate which is one of the most competitive school examinations in Pakistan.The study involved 32 participants including administrators, teachers and students. Table 1 provides details of the participants of the study:

Table 1

Details of research participants of St. Sylvester and Aly Salman High School

\begin{tabular}{ccccccc}
\hline Schools & $\begin{array}{c}\text { Administrators } \\
\text { (pre-medical } \\
\text { group) }\end{array}$ & $\begin{array}{c}\text { Teachers } \\
\text { (pre- } \\
\text { medical } \\
\text { group) }\end{array}$ & \multicolumn{2}{c}{$\begin{array}{c}\text { Students } \\
\text { (pre-medical group) }\end{array}$} & Total \\
\cline { 1 - 2 } & 2 & 4 & 4 & 2 & 4 & 16 \\
\hline $\begin{array}{c}\text { St. Sylvester High } \\
\text { School }\end{array}$ & 2 & 4 & 4 & 2 & 4 & 16 \\
\hline $\begin{array}{c}\text { Aly Salman High } \\
\text { School }\end{array}$ & & & $\begin{array}{c}\text { Below } \\
\text { Average }\end{array}$ & Average & $\begin{array}{c}\text { Above } \\
\text { Average }\end{array}$ & \\
\hline Total number of research participants from both the cases & & & 32 \\
\hline
\end{tabular}


As shown in table one, participants in both schools included four administrators, eight teachers of the pre-medical groups and twenty students of premedical group selected from below average, average and above average category based on their academic performance.This study analyzed the data in two steps: firstly within the specific settings of St. Sylvester High School and Aly Salman High School and then across case settings. This was done to understand the similarities and differences between the two selected schools(Baxter \& Jack, 2008). After the completion of the analysis of St. Sylvester High School and Aly Salman High School independently, cross case analysis was done for external validity, to offer generalizations and to highlight contextual variation across the selected schools (Cohan et al., 2018; Gay et al., 2015; Merriam, 2009; Yin, 2013).All planned interview recordings were transcribed verbatim then analysed using constructionist thematic analysis methods developed by Perry (2013), Ritchie et al. (2013) and Braun and Clark (2006). Thematic analysis was used as it is well suited for case studies analysis (Patton, 2015).

\section{Discussion}

\section{Impact of Care on Affective Domain of Learning}

Affective domain is the second domain of learning that focuses on the learning of attitudes, behaviors and physical skills involving feelings, emotions and attitudes (Hoque, 2017). Research participants St. Sylvester High School and Aly Salman High Schoolhave explicitly narrated that care impacts the learning of students at the first three levels of affective domain entitled as receiving, responding and valuing. Students at the receiving level are aware of and sensitive to the existence of certain ideas, material, or phenomena and are willing to tolerate them. Hence they listen and accept the phenomena, ideas and material shared by the teacher.Students at valuing level show willingness to be perceived by others as valuing certain ideas, materials, or phenomena. The mean value obtained of receiving and valuing levels of St. Sylvester School and Aly Salman School two is lesser in comparison to responding level. Therefore activities relating engrossment and motivational displacement from teachers' end may not have been sufficient to have greater influence on the learning of students.

This could be due to lack of intrinsic motivation to get actively involved in the learning of students. The mean value of responding level is higher in both the schools but in comparison to Aly Salman High School it is higher in St. Sylvester High School. This might be due to the fact the boys striving towards high score and grades to compete for admissions into colleges of reputation. Aly Salman being coeducation and girls in Pakistan have comparatively fewer choices for college admissions considering factors such as distance from residence, fee structure, social and political environment, socio economic background of the family to support the education of female children. However students in both the schools seem to be committed in responding to the ideas, materials and phenomena communicated by the teachers by being actively involved in it. Thus they comply with, 
follow, commend, volunteer and acclaim to the ideas and material presented by the teachers. The table given below shows the similarities between the selected schools regarding the impact of care.

Table 2

Similarities between the selected schools regarding the impact of care

\begin{tabular}{ccccc}
\hline $\begin{array}{c}\text { Impact of care } \\
\text { relating to the } \\
\text { levels of } \\
\text { affective } \\
\text { domain }\end{array}$ & $\begin{array}{c}\text { St. Sylvester } \\
\text { High School }\end{array}$ & $\begin{array}{c}\text { Mean of St. } \\
\text { Sylvester } \\
\text { High School }\end{array}$ & $\begin{array}{c}\text { Aly Salman High } \\
\text { School }\end{array}$ & $\begin{array}{c}\text { Mean of Aly } \\
\text { Salman High } \\
\text { School }\end{array}$ \\
\cline { 2 - 5 } Receiving & $\begin{array}{c}\text { Teachers, } \\
\text { Students }\end{array}$ & 37.5 & $\begin{array}{c}\text { Administrators, } \\
\text { Teachers } \\
\text { Students }\end{array}$ & 43 \\
\hline Responding & $\begin{array}{c}\text { Administrators, } \\
\text { Teachers } \\
\text { Students }\end{array}$ & 80 & $\begin{array}{c}\text { Administrators, } \\
\text { Teachers } \\
\text { Students }\end{array}$ & 71 \\
\hline Valuing & $\begin{array}{c}\text { Administrators } \\
\text { Teachers } \\
\text { Students }\end{array}$ & 30 & $\begin{array}{c}\text { Administrators } \\
\text { Teachers } \\
\text { Students }\end{array}$ & 31 \\
\hline
\end{tabular}

The interview responses specify that students at St. Sylvester High School and Aly Salman High School are not journeyed to the fourth level of affective domain that is entitled as organization. Thus they are not supported to relate the value learnt to those already held and bring it into a harmonious and internally consistent philosophy. This signifies that students are not involved in activities such as discussion, theorizing, formulation, balancing and examining. Characterization is the fifth and the highest level of affective domain. Students at this level can act consistently in accordance with the values internalized. Teachers' journeying students to reach this level enables them to revise, require, avoid, resist, manage and resolve phenomena encountered.

\section{Impact of Care on Cognitive Domain of Learning}

Respondents of St. Sylvester High School described that care has a very strong impact on the learning of students at remembering and understanding levels of cognitive domain. The interview responses of research participants ascertain that students of St. Sylvester High School are cared for their learning at remembering level that develop their proficiency in reciting something taught to them and recalling information from memory based on previous lectures, reading materials and notes taken during teaching sessions. Respondents of St. Sylvester High School also explained that students in their school are cared for their learning at an understanding level too. The impact of care at this level is that students are able to explain concepts in their own words such as paraphrasing a story or definition.

The responses of the research participants of St. Sylvester High School clearly indicate that care has an impact on the learning of students at the first two levels of 
cognitive domain. The interview response did not show any evidence of care by teachers impacting the learning of students at higher level such as applying, analyzing, evaluating and creating. This specifies that students are not encouraged to extend their learning outside the classroom and relate it with their real world experiences. The interview responses do not give an indication of developing critical thinking skills in students to help them learn how or why different concepts work together. Taking interview responses as evidence it is assumed that students are not motivated to make value judgments about the content taught to them and neither are they encouraged to manifest their knowledge by building something tangible or conceptual (Bolin et al., 2005).

The respondents of Aly Salman High School associated the outcome of care with building rapport between teachers and students. Teachers having strong bonds with students help them to solve their academic or personal problems and students respond to this bond through achieving academic excellence and teachers turn out to be effective. The bond becomes a source of motivation for students to participate in classroom activities hence having a huge impact on the learning of students through improved performance in academics. The table given below shows the differences between the selected schools regarding the impact of care.

Table 3

Differences between the selected cases regarding the impact of care

\begin{tabular}{ccccc}
\hline Impact of care & \multicolumn{3}{c}{ Differences between both the school } \\
\cline { 2 - 3 } Remembering & $\begin{array}{c}\text { Stakeholders } \\
\text { of St. } \\
\text { Sylvester } \\
\text { High School }\end{array}$ & $\begin{array}{c}\text { Average mean } \\
\text { of St. } \\
\text { Sylvester } \\
\text { High School }\end{array}$ & $\begin{array}{c}\text { Stakeholders } \\
\text { of Aly Salman } \\
\text { High School }\end{array}$ & $\begin{array}{c}\text { Average } \\
\text { mean of Aly } \\
\text { Salman } \\
\text { High School }\end{array}$ \\
\hline & $\begin{array}{c}\text { Administrators } \\
\text { Teachers } \\
\text { Students }\end{array}$ & 66.6 & \\
\hline Understanding- & $\begin{array}{c}\text { Administrators } \\
\text { Teachers } \\
\text { Students }\end{array}$ & 61 & \\
\hline $\begin{array}{c}\text { Rapport between } \\
\text { teacher and } \\
\text { student }\end{array}$ & \multicolumn{3}{c}{$\begin{array}{c}\text { Administrators } \\
\text { Students }\end{array}$} \\
\hline
\end{tabular}

Stronge (2007)argues that the rapport between teachers and students help teachers knowing students individually understand students' learning styles, needs and plan teaching accordingly that may cause a modification in the behaviour of students towards academics, personal situations, schooling and peers. 


\section{Conclusion}

The findings of the current study are supported by literature as it has also associated caring impact with improved academic performances and high achievement in the form of better grades. The research findings explain that care by teachers has greatly influenced the learning of students at responding level. An outcome of care associated with students' development of interest in the subject, active participation in class discussion and group presentations, and completion of assignments. Students respond to teachers caring in the mentioned ways to score better marks in examinations leading towards the attainment of better grades (Louis et al., 2016; Noddings, 2010). The research findings indicate that learning in the selected schools is restricted and limited to grades at the cost of ignoring the development of subject specific competency. The study has identified the impact of care with knowledge, skills and attitudes developed at various levels of cognitive and affective domains of learning.

\section{Recommendations}

Ethics of care and morality should be a driving force for teaching and learning. Giving respect and listening to the students' opinions and point of views are of pivotal importance to develop the culture of care. Therefore the curriculum for the teacher education programme and courses need to include practical exercises and activities focusing on effective listening and respecting different opinions. It is also recommended for the schools to develop mechanisms to increase the involvement of the students in some extent for the decision making process and seeking their feedback on the processes involving their affairs by the school management. The need for including component of care ethics in the curricula of teacher education programmes is also because now in the globalized era, there are students from culturally diverse backgrounds in the classroom. The teachers need to know about the cultural values and sensitivities so as to provide caring support to the students in their physical, social, emotional, cognitive and spiritual developments (Falkenberg, 2009; Owens \& Ennis, 2005; Thompson, 2018; Thornberg \& Oguz, 2016). 


\section{References}

Ahmad, I., Rehman.K, Ali, A., Khan. I. \& Khan, F.A. (2014). Critical Analysis of the Problems of Education in Pakistan: Possible Solutions. International Journal of Evaluation and Research in Education, 3(2), 79-84.

Ahmad, I., Said, H., \& Khan, F. (2013). Effect of corporal punishment on students' motivation and classroom learning. Rev. Eur. Stud., 5, 130.

Aly, J. H. (2007). Education in Pakistan. A white paper revised. Document to debate and finalize the National Education Policy.

Bergmark, U., \& Alerby, E. (2006). Ethics of care: a dilemma or a challenge in education? In AARE 2006 International education research conference: 26/11/2006-30

Bolin, A. U., Khramtsova, I., \&Saarnio, D. (2005). Using student journals to stimulate authentic learning: Balancing Bloom's cognitive and affective domains. Teaching of Psychology, 32(3), 154-159.

Cohen, L; Manion, L \&Morrision, K. (2018). Research Methods in Education (8th ed.). New York, USA: Routledge.

Engster, D., \& Hamington, M. (Eds.). (2015).Care ethics and political theory. Oxford,UK: OUP.

Falkenberg, T. (2009). Starting with the end in mind: Ethics-of-care-based teacher education. Counterpoints, 334, 50-59.

Garrett, T., Barr, J., \& Rothman, T. (2009). Perspectives on caring in the classroom: Do they vary according to ethnicity or grade level? Adolescence, 44(175).

Gay, L.R; Mills, G.E; \& Airasian, R,W (2015). Educational Research: Competencies for analysis and application (10th ed.).London, UK: Pearson.

Ghazi, S. R., Shahzada, G., Tariq, M., \& Khan, A. Q. (2013). Types and causes of students' disruptive behavior in classroom at secondary level in Khyber Pakhtunkhwa, Pakistan. American Journal of Educational Research, 1(9), 350-354.

Gilligan, C. (1982). In a different voice. Cambridge, UK: Harvard University Press.

Goldstein, L. S., \& Lake, V. E. (2000). "Love, love, and more love for children": exploring preservice teachers' understandings of caring. Teaching and Teacher Education, 16(8), 861-872.

Hamington, M. (2010). The will to care: Performance, expectation, and imagination. Hypatia, 25(3), 675-695. 
Hoque, M. E. (2016). Three domains of learning: Cognitive, affective and psychomotor. The Journal of EFL Education and Research, 2(2), 45-52.

Louis, K. S., Murphy, J., \& Smylie, M. (2016). Caring leadership in schools: Findings from exploratory analyses. Educational administration quarterly, 52(2), 310-348.

Merriam, S. B. (2009). Qualitative Research: A guide to design and implementation. San Francisco, USA: Jossey-Bass.

Monchinski, T. (2010). Education in hope: Critical pedagogies and the ethic of care (Vol. 382). Peter Lang.

Mortari, L. (2016). For a pedagogy of care. Philosophy, 6(8), 455-463.

Mughal, A. W. (2020). Secondary school students who drop out of school in rural Pakistan: The perspectives of fathers. Educational Research, 62(2), 199-215.

Narinasamy, I. (2018). The Need to Care: Students' Perceptions of Teacher's Caring Behaviour. Retrieved from, https://www.researchgate.net/profile/Ilhavenil_Narinasamy/publication/3266 68365_The_Need_to_Care_Students'_Perceptions_on_Teacher's_Caring_Behavio ur/links/5b6e770345851546c9fa5ab1/The-Need-to-Care-Students-Perceptionson-Teachers-Caring-Behaviour.pdf

Noddings, N. (1984). A Feminist Approach to Caring About What We Care For. Gender/Body/Knowledge. Feminist Reconstructions of Being and Knowing, Eds, Jaggar, Alison M, Bordo, Susan R, 183-185.

Noddings, N. (2003). Is teaching a practice? Journal of Philosophy of Education, 37(2), 241-251.

Noddings, N. (2010). The maternal factor: Two paths to morality. California, USA: University of California Press.

Noddings, N. (2012). The caring relation in teaching. Oxford review of education, 38(6), 771-781.

Nguyen, M. J. (2016, April). Understanding the role of caring in teaching. In Annual Conference the Philosophy of Education Society of Great Britain.

O'Connor, K. E. (2008). "You choose to care": Teachers, emotions and professional identity. Teaching and Teacher Education, 24(1), 117-126.

Owens, L. M., \& Ennis, C. D. (2005). The ethic of care in teaching: An overview of supportive literature. Quest, 57(4), 392-425 
Owusu-Ansah, A., \& Kyei-Blankson, L. (2016). Going Back to the Basics: Demonstrating Care, Connectedness, and Pedagogy of Relationship in Education. World Journal of Education, 6(3), 1-9.

Rashid, K., \& Mukhtar, S. (2012). Education in Pakistan: Problems and their solutions. International Journal of Academic Research in Business and Social Sciences, 2(11), 332.

Rivera-McCutchen, R. L. (2012). Is Small All: A Study of the Intersecting Factors Contributing to the Successes and Challenges of a Small Bronx High School (Doctoral dissertation, New York University, School of Education).

Rojas, L., \&Liou, D. D. (2017). Social justice teaching through the sympathetic touch of caring and high expectations for students of color. Journal of Teacher Education, 68(1), 28-40.

Silverman, M. (2012). Virtue Ethics, Care Ethics, and" The Good Life of Teaching". Action, Criticism, and Theory for Music Education, 96-121.

Stronge, J. H. (2018). Qualities of effective teachers. Retrieved from, https:// www.middleweb.com/38903/reflect-on-the-qualities-of-effectiveteachers/\#: :text=Stronge $\%$ 20identifies $\% 20$ six $\%$ 20qualities $\% 20$ of, $\% 2 C \%$ 20learni ng\%20environment $\% 2 \mathrm{C} \% 20$ and $\% 20$ professionalism.

Thompson, C. S. (2018). The Construct of 'Respect' in Teacher-Student Relationships: Exploring Dimensions of Ethics of Care and Sustainable Development. Journal of Leadership Education, 17(3).

Thornberg, R., \&Oğuz, E. (2016). Moral and citizenship educational goals in values education: A cross-cultural study of Swedish and Turkish student teachers' preferences. Teaching and Teacher Education, 55, 110-121.

Watson, W., Sealeya-Ruiz, Y., \& Jackson, I. (2016). Daring to care: The role of culturally relevant care in mentoring Black and Latino male high school students. Race Ethnicity and Education, 19(5), 980-1002. 